\title{
Socio-Environmental Condition Of Women At Prison: A Case Study Of Karachi Central Jail
}

\author{
Dur-e-Shehwar Baloch \\ Institute of Women Development Studies \\ University of Sindh \\ Parveen Shah \\ University of Sindh \\ \& \\ Misbah B Qureshi \\ Institute of Women Development Studies \\ University of Sindh
}

\begin{abstract}
This paper proposed to discuss the socio-environmental conditions of women at prison in Karachi. ${ }^{1}$ Prison is kind of punishment in which people are physically restricted of a range of personal freedom. Besides this, in jail manual, women have been protected by different rules and regulations. This paper is an explanatory study based on quantitative and qualitative research methodology. The questionnaire method was used for the purpose of data collection. The study shows that the situation on ground and the conditions of women prisoners is not good. In Pakistan rules and laws are available however, they are not implemented. This paper also suggests measures and recommendations in order to overcome the unhealthy and unhygienic condition faced by women prisoners at Karachi Central Jail.
\end{abstract}

\section{تلخيص مقال}

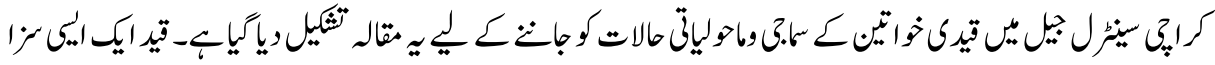

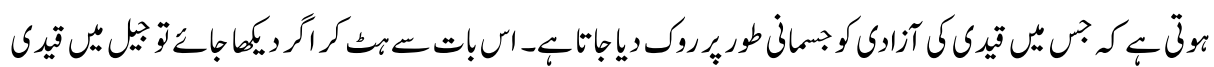

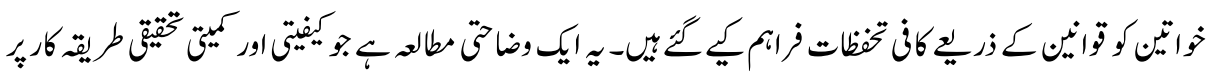

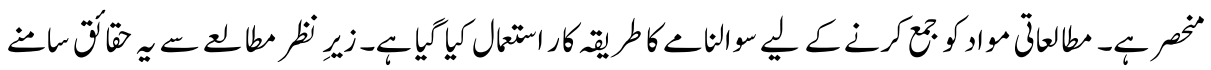

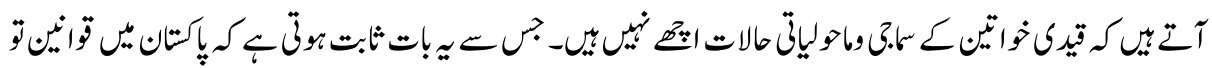

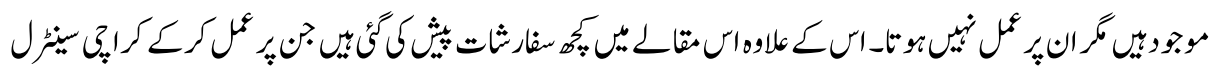

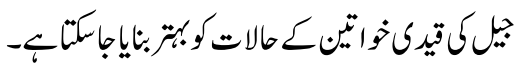




\section{Introduction}

The jail system is one of the inventions created due to creation of human society system. The basic concept of jail system is to punish the criminals, for at the end for their betterment so that they do not indulge in crimes any more.

"A prison is a place in which people are physically confined and, usually, deprived of a range of personal freedom". ${ }^{2}$ It is a kind of punishment, which has its own logic based upon different reasoning and the basic logic in this theory is revenge. In ancient civilizations, revenge was taken on individual level. If we look upon our prevailing environment, we can deduce that due to different riots, social structure of society is being up routed. Another logic is to undermine the will for criminals by punishing them and this punishment will also become an example for other not to follow any criminal proceedings. In this context, third logic presented in order to create some safe environment for the citizens.

The modern theory which has been presented for betterment of criminals is that "there should be a mental change in the attitude of criminals so, that they should start abhorring their criminal behaviour. This change definitely will be coupled with the educational and mental training of criminals" (HRCP, 1997).

"According to criminology and its further advancement it gave a picture that criminals are basically sick people due to some of social discontentment, so instead of punishing them they should be provided counselling and treatment. In modern societies especially USA reform programs for jails are established with a mission to convert prisoners into active and useful members of society. However, after 1970 this theory revealed lot of criticism and rising level of crimes in the society made the existing mechanism useless. In many cases and their studies revealed that criminals cannot be made useful for society by any method. The studies generated by Robert Martins resulted that to achieve this goal no plan is workable" (Malik, 2000).

Robert Johnasan and Jackson Toni both had same idea that criminal should get their due shares in jail. However, due to over burdening, many jails lack basic health facilities and these should be utilized for basic punishments only. According to Plato "A criminal after getting his punishment should become a better human, if not, then he should return to the society as a cursed one" (Malik. 2000). The Plato theory was to punish only up to that extent that the criminals get corrected. However, situation is opposite in our jail system; criminals become more hardened and this nullifies the main aim of jail and even the extreme punishment does not generate the desired effects. 
Jails have a manual and every province has a different jail manual under the Federal Act, which is called Prisoners Act. This act was regulated by the British Government in 1818 and was one of the reasons to trigger the independent struggle in 1857. This prison Act was implemented in 1894; it received few modifications in 1900. However, it has been implemented in 1947 throughout Pakistan (HRCP, 2000).

The rules and regulation implemented in jail are judged by the jail manual. It also dictates the rights of a prisoner. The human rights are very basic in nature irrespective of either human is behind the bars or a free person. Keeping this in view, it has been considered that a prisoner is a human being first. In the same way, If we critically analyse the women prisoners and their rights in jail manual, it becomes evident that while preparing and regarding their implementation, women prisoners have been given due sympathetic consideration.

In jail manual, women have been protected by different rules and regulations. However, if we see the situation on ground and the conditions of woman prisoners then we come to know that in Pakistan rules and laws have not been implemented. By analysing the condition of women imprisoned in Khyber Pakhtoon Khawa (KPK) jails, the situation of prisoners becomes very vivid and clear. According to a report of Human Rights Commission of Pakistan (HRCP) in 1997, published after the visit of 15 jails in Khyber Pakhtoon Khawa, drew the following remarks:

"KPK has 21 jails in total with no separate jail for women prisoners. 156 women were found imprisoned. 84 were married and 72 were unmarried. Most of the women and infants were in central jail Peshawar. $85 \%$ of the prisoners were under custody for zina ordinance. $75 \%$ were in need of some legal help. $85 \%$ women, pregnant women and infants lacked proper food facility. $75 \%$ women were not able to meet their blood relatives. Out of 156 only 60 women had been convicted by the court, rest of all were under trial" (HRCP, 1997).

Another study of all 86 jails of Pakistan found the same situation and the main reason is lack of funds provided by the Government of Pakistan. The funds which are allocated for the welfare of prisoners are also not released on time. The shortage of food in jails is not a new phenomenon. It is often observed that the food suppliers to jail don't supply according to their bids. The contractors have the plea that they are not paid accordingly. This problem is not related to payment to contactors only. It is also related to the fund allocation in fiscal budget. Nine rupees, seventy three paisas (Rs 9.73) has been allocated for three time meals for a prisoner, but according to budget this amount should be six rupees, thirty four paisas (Rs. 6.34) per prisoner. According to the most observers even this limited amount is not spend for prisoner's food requirement. The rates of meat, vegetables, milk and beans approved by jail department are very less as we compare from 
actual rates. So according to them, purchasing of these items is not possible. So, it means either the supplier would provide low quality items, or it will not provide full quantity according to supply order or may result in corruption" (HRCP, 1998).

Another problem that is common in jails is lack of means of communication. According to Annual report 2002 of Pakistani Commission for Human rights, the delay in judgment of prisoners and unavailability of the vehicles is the main cause of rush in jails. Mostly the confinement of under hearing prisoners has prolonged even for many years because they don't bring them timely in courts. Preference is given to the prisoners who commit offenses for example sectarian offences or in bribe cases. So prisoners with minor offences are deprived of quick judgement. "Now it becomes a custom in Pakistan that all suspected people, in police custody are targeted by different methods of causing trouble except those who can buy the safety of their lives. In Pakistan, the different methods of causing troubles in jails, includes prisoners in chain and beat them by boots/ shoes" (HRCP, 1997).

Females are also targeted by sexual harassment by police staff; it is very difficult for a woman to protect herself. The police have very negative reputation with reference to violence in jails. If the arrested woman belongs from the poor family, then their helplessness makes them unsafe in hands of police and exploited. Hudood Ordinance has been used for the registration of cases which creates galling situation for the offender. It could be easily found out by an example in 1997, in a police station of Karachi, a woman naming Manzoora was targeted by sexual harassment. After this, police has registered a case under Hudood Ordinance. (HRCP, 1997)

There are unlimited problems in jail only some events occur conspicuously. The most important problems in jail is the presence of prisoners more than its capacity. Actually due to this problem, prisoners in jail, face many other problems. Like unavailability of primary facilities, which includes proper food, clean water, and medical facilities. Most of female prisoners and their kids are facing these problems. In jails, mostly females face cases under Hudood Ordinance cases. These cases are registered by their brothers, husbands, father or other relatives. These women are convicted due to love marriages, refusal of arrange marriages by parents or separation from cruel husbands or denial from becoming prostitutes. Hudood Ordinance is a big example of exploitation of women. In which, there is a probability that, any women could be engaged in fake case of zina, in order to take revenge. Because, as for the Zina, a woman alleging rape is required to provide four adult male eyewitnesses. In many cases, the failure to find such proof of the rape places the woman at risk of prosecution for Zina. Only in Lahore Central Jail, according to the statistics, taken in mid of 1997, out of 77 females, 29 were imprisoned under this law. It is a reality that "most of them were discharged" in result of appeal. However, during this they face so many problems, which cannot compensate. 
Hudood Ordinance was passed in 1977 in Zia ul Haq Government. The Poor women suffer more from Hudood Ordinance because the people earning more income are able to escape from laws on the basis of their wealth. Respected position of women deteriorates if she is sent to jail being accused of zina, whether she is wealthy or poor. Most of the time zina-bil-jabar, case transferred into, zina-bil-raza because victims of zina-bil-jabar are facing situation of not getting justice in court case. However, punishment of Hadd has never been executed in Pakistan but according to Pakistan panel code punishment, thousands of women has been harassed, blamed, sent to jail and are punished. According to this ordinance, women witness will not be accepted even in the case of zian-bil-jabar, which is a big disadvantage for women. The police provide support to the people involved in these cases. In respect of providing safety to the woman, they harass her. The men use these laws openly to control the women of their own family. This law is an unreasonable weapon in the hand of people who want to accuse women.

\section{Objectives}

The objectives of this study are:

1. To examine the mode of living of women in the Karachi Central Jail (KCJ).

2. To analyse the physical and mental condition of women in KCJ.

3. To know about the children of women prisoners in the KCJ, either their kids are inside the jail or not. If they are in jail then what will be their conditions.

4. To know about the attitude of staff towards the women in KCJ.

5. To know about the attitude of the relatives of the women in KCJ.

\section{Data and Methodology}

The present research is quantitative and qualitative research, based on explanatory study. It deals with women prisoners' socio-environmental situation at Karachi central Jail. The sample size of seventy five (75) respondents were randomly selected under the charges of rape, incest, kidnapping, smuggling and murder etc. For this study purposive sampling method was used which is a type of non-probability sampling. The questionnaire method was used for the purpose of data collection; questionnaire was made in such a way that, it covered all the important aspects of the research problem. It consists of both close and open-ended questions, through this data was collected and analyzed.

\section{Analysis \& Results}

In Karachi Central Jail, 52\% women have been in the jail for less than 6 months, $18 \%$ has been in the jail for more than 6 months but less than 1 year. However, there was a woman who had been in the jail for the last five years. More than $38 \%$ of women in Central Jail 
are victimized under Hudood Ordinance whereas remaining are involved in narcotics, smuggling, kidnapping, murder, fake passports.

Also, only 4\% women have some knowledge about the $\mathrm{B}$ and $\mathrm{C}$ categories. However, the remaining $96 \%$ have no idea about the $\mathrm{B}$ and $\mathrm{C}$ classes at all. They are considering the $\mathrm{B}$ and $\mathrm{C}$ classes as the barrack numbers. One of women told that, in the morning every woman put 20 to 25 buckets of water in drain, which is a very difficult task for them. Also taking care of elder women and infants, washing clothes, studying, cooking and other, such hectic works are their daily routine. However, some of women told that they used to teach other children for monthly stipend. In contrast, some of the women have no work to do and the remain free for the whole day.

One of the women told,

"Early in the morning, I go for chapatti distribution, and on return try to sleep for a while then wake up for the breakfast at 8'o clock. At 9'o clock, I go to school for teaching for Islamiyat a monthly stipend of Rs. 500."

(Excerpt from interview).

$73 \%$ women told that usually the quarrel with each other on minor issues like the possession of different things, on their turn for bath and toilet, because of children etc. Sometimes, in extreme cases the minor issues would turn into big issues, which results in the fighting between them. Women admitted that the use of abusive language is a routine matter in jail.

One of them told that,

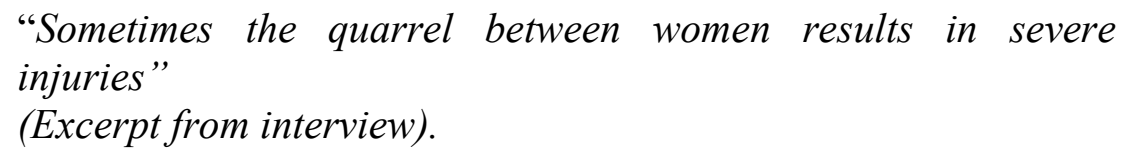

Women prisoners told that there are only two toilets for 40 to 50 Women Prisoners and they have to make queue to attend the toilet. Most of women told that they have to wait too long to take a bath. Also during periods, the administration does not provide them any extra support to help them in this situation. Such material is only provided to special women on discrimination basis, claimed by several women. Class difference is observe in jails where women from upper class and those spying for jail administration are provided better facilities as compare to other women prisoners. $52 \%$ of the women cook food themselves and the $46 \%$ of them use the jail food. Most of the women claimed that the jail food is not eatable and even some of them said" no ingredients or spices are added in 
the food, it contains of water and some lentil and even the source of meat is also doubtful". Another woman told that "usually lentils used in the jail food are of low quality and some times jail food contains the bad smell. If some NGOs or welfare organizations provide food it is only for 'VIP' ladies".

$63 \%$ of women told that there is no arrangement of any dietary food in case of medical problem. $69 \%$ of women told that medical facility is provided in case of medical problem in jail, however $6 \%$ of women said that no such facility is provided. Some of them said, "We have to make a queue for medical checkups and due to huge number of patients; sometimes medical treatment was not given". One woman told, "For any disease, they only give red and black tablets"

Regarding the work in jail, one woman told, "My responsibility is sweeping work, at that time nobody is there to take care of my children. They are always weeping and I am unable to attend them".

One woman told,

"During official round, we have to take double duty".

(Excerpt from interview).

Another woman told,

"I have to fill the water buckets early in the morning and I am 3 months pregnant". (Excerpt from interview).

The prisoner women said that, the jail staff notify but beat them with a stick if they are informed. One woman told she is afraid of going to matron because she is class conscious and rebuke accordingly. They further complain use of dirty language during rebuke.

$81 \%$ women admitted provision of recreational opportunities. Different Non Governmental Organizations (NGOs) also organizes functions in addition, TV is provided in each barrack but they are not working. Matron asks every woman to contribute Rs. five each to get these TV sets repaired. She also told that contribution is demanded for repair of items like tube lights, fans, water cooler, toilet and other usable items. All women said they do not want any recreational facilities or functions (organized by NGOs) but freedom.

There are difficulties in offering prayers. $11 \%$ women do not perform any prayer. Other $89 \%$ said they fulfil religious duties in barracks during nights and outside in daytime. 
However, 50\% women narrated different difficulties in performing of religious duties, such as shortage of water for ablution, dirty toilets, noises, bugs, cockroaches etc. One woman said that for a complete bath she had to wait for a month because everyone had to go on her turn. The powder provided by management for removal of hair for purity does not work. She said that she has only one brazier, which she is wearing for last one year. Under such conditions of impurity how she can perform religious acts.

Women informed they are taken out of barracks at morning on 06:30 to 04:30 in the evening. Relatives of $59 \%$ women visit them but they have to pay cash for these meetings. The amount varies according to status of visitors. One woman informed these meetings are not direct but a screen of wire gauge is between them. Another common complaint was about double expenditure for these meetings; one of the woman told that "on the time of court trial i meet my relatives, they do not come to jail to see me but they meet me on court only to save double expenditure because when they meet here we have to pay and when we meet in court we have to pay to jail staff". Relative of $13 \%$ do not come to see them due to financial problem. These women said that, their relatives don't have enough money to give to prison staff for meeting. Whereas $8 \%$ of women told that, they have no relatives. $9 \%$ of women do not know why their relatives are not coming to meet them. 3\% of women attributed social fear of their relatives, which prevent them to meet these prisoner women. These relatives fear meeting these relatives in prison may harm their social life and status in future.

Women told that their parents, children and husband visit jail to meet them. 29\% claim that these visits are on weekly basis, $12 \%$ women inform their relatives to come and see them after a month or more. $48 \%$ women told their relatives to bring clothes, cash, fruits and other eatable items but they don't get these items easily. They have to pay some cash to staff to get it. Some times staff retains the items which they like. According to one woman all these items are entered in a register by the staff. But often jail staff keeps or hide these items from women. One woman told that her relatives have to pay to staff Rs 25 up to Rs 50 for half an hour meeting. In addition, the staff keeps $50 \%$ of the items which my relative, has brought for me. In case of cash the amount is taken from us. $87 \%$ of the women informed that they get no special instruction from warden. Whereas 13\% women admitted warden given them different instructions such as no combing in barrack, cash should not be more than Rs 500 and to keep discipline. 100\% women informed that there is no male staff on duty in women section of prison. $97 \%$ says there should be no male staff in the women section. They gave different reasons for it such as purdah, feeling of insecurity and harassment.

$17 \%$ women informed they have not been taken to court for hearing so far. There were many women amongst who have not been taken to court for hearing for more than a year. Whereas 24 percent said they don't remember how many times they have gone for trial. 
They further explained mostly they reaches late or they were taken late intentionally. In such cases, time of judge in office mostly expires so they missed the trial. Some women told that, the matron and guards taking money from them and then they allow meetings with their relatives. Furthermore they said the staff charges start from six hundred to seven hundred Rupees, in addition to cash they also take food items such as plate of biryani, lassi etc. In this case the poor women and the women having no relatives get very bad treatment.

Children of $3 \%$ women live with their mothers in jail. $32 \%$ of women have no child. Children of $17 \%$ women are being supported by their in-laws and $12 \%$ by their parents. $84 \%$ women have said they will go to their home after release from jail. $8 \%$ said they do not know where they will go. One woman said that her relatives will not accept her so she will not go to them. One woman said her relatives abandoned her so she has no one to look after her. She will live on foot path after release. 5\% said they will go to some other country. Others had following reactions:

- $63 \%$ said their relatives will accept them with open arms

- $19 \%$ said their relatives would not accept them

- One woman was of the opinion that her relatives would not accept her because being in jail is a shameful spot on her life.

- $4 \%$ said they don't know how their relatives will behave on her return.

These women have different feelings about their future. 11\% worried about their future and had no clear idea, $15 \%$ said they will not do anything in future, $5 \%$ said they will shift their area of residence, $15 \%$ said they will try to find a job.

$84 \%$ woman said they did not encounter any special event in jail whereas $16 \%$ faced events in jail.

\section{Discussion}

There are several ways to tease a woman and these methods also affect their lives in different aspects. One of the examples is the laws enforced in Pakistan. Laws are basically made to safeguard the humanity, but in Pakistan, the laws relevant to woman are very complicated. One of them is the Hudood Ordinance. The movement against the Hudood Ordinance was started in 1981 when Fahmeeda Allah Baksh was sentenced of stoning to death and 100 Lashes". This was a case that they could not get entry of their marriage in the court. At last, the case was withdrawn. But after that, among many case, Safia bibi had to face an apocalyptic case in 1983, in which a blind girl was accused of "zina" (adultery). But in this case, only blind girl was sentenced of "zina" and the accused persons were released due to unavailability of evidences. After that, Safia bibi was released after facing many personal problems and disgrace. But in 2003, different non-government organization spoke against this ordinance but in vain (HRCP, 2003). 
With reference to love marriage, the supreme court validate that the Federal Shariat Court decision on Dec 19, 2003 and decided that with respect to Islamic shariyat, adult Muslim women can marry without the permission of the guardians or relatives(HRCP, 2003). Supreme Court validated the decision that a Muslim woman can marry with her consent only. The society does not think that jails can be used for the betterment of prisoners and so they have to live a disgraceful life in the society. The society thinks that the condition of Pakistani jails is such that it cannot be explained. Jails are overcrowded, due to which an accused or a criminal person comes out of jail in the form of a criminal instead of better human being.

$\mathrm{KCJ}$ is an example of an overcrowded jail where 307 women with their children are imprisoned in only six barracks. Only 139 beds are available to sleep and the remaining women and their children sleep on the mats. The jail superintendent is responsible for providing the cloths and beds to prisoners. But apart from a few, most of the women are deprived of these facilities. The main reason for this is jail staff which creates differences due to regional level.

If we see the condition of the KCJ under rule number 319 , the cleanliness of jail and the works involving physical labour are the responsibility of imprisoned women. Actually in jail, women are divided into two groups. One group of women is responsible for all the work and they work for the whole day while the other group is that which can give bribe to the jail staff to release them from any work. Moreover, those who have no money, have to work the whole day. Even the pregnant women have to work the whole day and have to fill can of waters for the jail staff.

According to the rule number 260 of Jail Manual, "the approved meal scale should be pasted outside the barracks", but this does not seem to happen. Also, the quality of the food is very low. This substandard meal provided to these women has very bad smell and even animals do not like to eat that food. Also according to rule number 473, "one type of "daal" will not be given twice during the same day. Vegetables given to them will be properly cut and cooked properly. 84 grams of beef per women will be given twice in a week instead of daal. Also, potatoes will be given to the sick person instead of beef". But in $\mathrm{KCJ}$, the meal given to the prisoners is not according to these rules but the meal given to them is cooked by the children jail prisoners who don't know that how to cook. So they can't cook food properly due to which women became sick often. The women, who can meet the expenses of good food, cook the food themselves and the poor women and their children can only look at the rich eating good food. 


\section{Conclusion}

The basic objective for building prison is to imprison and punish the criminals and to put them in a right path and rehabilitate them in order to keep peace in the society. But with the advancement the basic objective remained same but the method of rehabilitation became worst. Now the conditions of the prison are proven the worst for humanity. In Central Jail Karachi, the conditions of women prisoners demonstrate almost the same situation as all of the prisons. The six prisons have more than its capacity of female prisoners with children. Over 300 women with 59 children. Hence the conditions of living and food are adversely affected. The main reason is that the rules and regulations of the jail are poorly followed and the administration is not fulfilling their duties. They are completely ignored by the situation. Government also stands responsible for the rapid increase in the population of the prisoners but no increase in the number of prisoner's barracks.

The constitution /law explain the duties of every responsible person but the people are completely ignoring their duties. Those laws, which are for gender discrimination, cannot be ignored and the Hudood Ordinance is one of them. If any woman get illegal status then it would be very difficult for her to survive her social life after releasing from the jail. She has to face the curses of the society and also her relatives. It makes it very difficult for her to survive in the society. We cannot figure out that who is responsible for this situation as it is the collective responsibility of our society. If we will not look into this matter, one day our families will also suffer from that. So we have to raise our voice collectively against the discriminatory laws and for the betterment of our society.

\section{Recommendations}

1. The budget of the prison has to be increased so that the basic need of the prisons should be met accordingly. The jail administrator should be properly paid as they will better take care of the prison.

2. The relief from the organization should be directly distributed by them. So that there will be no injustice.

3. The proper medical facilities should be available in the prisons. There should be regular visits at least in a month, of a qualified gynaecologist.

4. The mentally upset patient should not be kept in the jail

5. Female should be given proper treatment during their periods.

6. There should be ten more toilets in the female prison.

7. Proper transport facilities should be available for the hospital.

8. Jail administration should maintain the regulation to maintain female prisoner to attend their hearing in the court.

9. Every month there should be proper use of pesticides in the jail barracks.

10. There should be proper payment to the female prisoners for their work in the jail. 
11. Those who's cases are in court should not be imprisoned but maintained at payroll.

12. They should be aware about the follow up of their cases with their lawyers.

13. Young boy or girl over 5 year of age should not be kept with ladies in the prison.

14. During the visits with their families, they should have the proper rights like a political prisoner.

15. There should be strict check on the admission so they will not charge any visitor to the jail.

16. Visitors should not allow bringing edibles.

17. Police should also restrict visitors therefore it will eliminate the class system in the jail.

18. The law of hudood ordinance should be revised and should be amended otherwise cancel the law so that the innocent females will get free.

19. There should be proper registration of the love marriages on the court level.

20. A, B, C classes of prisons should not be allotted with the class system of the society.

\section{End Notes}

1 A metropolitan city of Pakistan.

2 http://en.wikipedia.org/wiki/Prison.

3 Zina is defined as sexual intercourse between a man and a woman who is neither his wife nor his slave. In modern states adhering to Islamic law, slavery is forbidden, and so zina encompasses extra marital sex \& premarital sex. Islamic law prescribes punishments for Muslim men and women for the act of Zina.

4 Stoning, or lapidating, is a form of capital Punishment whereby a group throws stones at a person until the person dies. No individual among the group can be identified as the one who kills the subject.

\section{References}

Aulakh, A. Majeed Ahmed \& Khan, Muhammad Masood. (1999) Pakistan Prison Rules 1978 (Jail Manual) Lahore: Kausar Brothers.

Daniel, A. E. et al (1988). "Lifetime and six-month Prevalence of Psychiatric Disorders among Sentenced Female Offenders." Bulletin of the American Academy of Psychiatry and the Law.

Good, Villiam and J, Helt PK. (1952) Method in Social Research, New York: Thirenillam Scs. 
Greenfield. L.A. and T. Snell (1999). Bureau of Justice Statistics Special Report: Women Offenders. U.S. Department of Justice, Washington, DC.

Jami, Muhammad Saleem. (1997) Hudood ordinance, Zina ordinance, Karachi: Lawyers for Human Rights.

Malik, Rasheed. (2000) Jarayam aur Mujrim , Lahore: Mashal.

Martin, S. (et al.) (1995). "Family Violence and Depressive Symptomology among Incarcerated Women ." Journal of Family Violence 10 (4).

Saghar, Riyaz ur rehman. (1996) Sarkari Mehmaan Khana, Lahore: Maktaba Aaliya.

Singh, Krishna Hathi. (2001) Zilatoon ki Maari Aurtein, Lahore: alfaz.

Walby, Silvia. (1990) Theorizing Patriarchy, Cambridge: Basil Black Well.

Young, P.V. (1956) Scientific Social Survey and Research, Tokyo: Prentic.

http://en.wikipedia.org/wiki/Prison.29Oct,2010. 17:34:52 GMT.

http://en.wikipedia.org/wiki/Zina. 1 Aug 2011 20:52:35 GMT.

http://en.wikipedia.org/wiki/Hudood_Ordinance. 31 Jul 2011 04:52:06 GMT.

Dur-e-Shehwar Baloch is Lecturer in Institute of Women Development Studies, University of Sindh, Jamshoro.

Prof. Dr. Parveen Shah is Pro-Vice Chancellor, University of Sindh, Jamshoro.

Dr. Misbah B Qureshi is Assistant Professor and Director of Institute of Women Development Studies, University of Sindh, Jamshoro. 